\title{
MULTI-GROUP MODELING OF PROTECTION AGAINST NEUTRON AND GAMMA RADIATION BY MATERIALS BASED ON TITANIUM HYDRIDE
}

\author{
Roman N. Yastrebinsky, Alexander A. Karnaukhov \\ Belgorod State Technological University Named After V.G. Shoukhov, \\ Belgorod, Russian Federation \\ E-mail:yrndo@mail.ru
}

The paper provides a comparative calculation of the radiation protective efficiency of various composite materials based on titanium hydride using multi-group modeling methods using the ANISN program. The calculations showed the high efficiency of titanium hydride composites with respect to neutron and gamma radiation. The relaxation length of the fast neutron flux density in titanium hydride materials is $5.1 \ldots 7.0 \mathrm{~cm}$. The spatial-energy distribution of neutron radiation in materials is formed by fast neutrons. The dose rate of gamma rays behind the material is determined mainly by capturing gamma rays arising in the initial layer of protection. Introduction to the composition of the protection of boron atoms reduces the level of capture gamma radiation, but does not affect the attenuation of fast neutrons.

\section{INTRODUCTION}

The design of radiation protection of nuclear power plants (NPP) is a multi-stage process based on the search for optimal solutions to ensure the radiation safety of maintenance personnel and to protect the reactor plant equipment from unacceptable radiation damage, i.e. weakening of the basic values of the functionals of ionizing radiation to the maximum permissible values [1].

In the process of designing radiation protection, the necessary modeling of protective properties is carried out using multi-group and statistical calculation methods, the results of which determine the composition, geometry and thickness of the protection. For a calculated or known radiation intensity of a nuclear reactor, it is necessary to select the composition of protection in such a way that it provides thermal and biological protection, as well as equipment protection to the established maximum permissible standards. At the same time, biological protection is of primary importance, which ensures the protection of staff and the public from radiation [2].

The design of the radiation protection of NPP is a multi-stage process based on the search for optimal solutions to ensure the radiation safety of maintenance personnel and to protect the reactor installation equipment from unacceptable radiation damage, i.e. weakening of the basic values of the functionals of ionizing radiation to the maximum permissible values [1].

In the process of designing radiation protection, the necessary modeling of protective properties is carried out using multi-group and statistical calculation methods, the results of which determine the composition, geometry and thickness of the protection. For a calculated or known radiation intensity of a nuclear reactor, it is necessary to select the composition of protection in such a way that it provides thermal and biological protection, as well as equipment protection to the established maximum permissible standards. At the same time, biological protection is of primary importance, which ensures the protection of staff and the public from radiation [2].

The task of designing protection can be seen as the opposite in relation to the calculation of the attenuation of radiation from the given sources. In this case, the initial data used by the maximum permissible radiation levels for protection, and the desired quantities are the parameters of protection. This task is performed by the method of successive approximations based on the approximations of the security settings using the following program code calculates the basic functionals of the radiation. The results of the comparison of the values obtained functionals with the maximum permissible values of the adjustments accepted part of the protection with the subsequent performance of the calculation. The final composition of protection, thickness and geometry of the layers is produced when the coincidence of the calculated values of the functionals with the specified maximum permissible values $[1,2]$.

Thus, the main challenge in designing is finding the necessary optimality criterion, and choosing the best variant of development of the set of the admissible in accordance with the quality indicators. The optimality of the solution selected depends on the number of options considered and the variation area of the main technical parameters affecting performance. The most important parameters when designing radiation shielding reactor materials are nuclide composition of the fillers, the binder matrix used for the calculation of the basic functionals of attenuation of neutron and gamma radiation as well as thermal, structural, mechanical, chemical properties and radiation resistance of the final composite. Used fillers, as a rule, should provide multi-level performance of radiation protection. In this direction promising the use of functional fillers having high radiation shielding properties, but also a high compatibility with the binder matrix $[3,4]$.

When choosing a filler, special attention is paid to materials with a high specific density of hydrogen atoms, which effectively slow down fast neutrons. The choice of binders is limited by the requirements for the 
mobility of mixtures due to the need to fill radiation protection structures of complex geometry and inaccessible places [5-8].

To a large extent, the requirements for compact protection of transport NPP are met by designers based on titanium hydride materials and, above all, products based on compact titanium hydride (CTH) with hydrogen atoms up to $3.5 \mathrm{wt} \%$ and titanium hydride fractions (THF) with a hydrogen atom content of up to 3.6 mass \%, which have found application in a number of projects [9-11].

To assess the protective effectiveness of various composite materials based on titanium hydride, this paper presents comparative calculated data using multigroup modeling methods. The performed calculations are estimates and made for hypothetical compositions.

\section{MATERIALS AND METHODS}

To conduct computational studies used a composition based on a CTH, THF, the fraction of titanium hydride and portland cement (PC) with different water-cement ratio (CTHF). It also describes boron-containing compositions of the composites as well as comparative analysis with serpentinite concrete.

Variation calculations of spatial-energy distribution of neutrons and $\gamma$-rays in materials protection were carried out according to the program ANISN [12], designed for solving one-dimensional transport equations of the theory of radiation transport by discrete ordinates, taking into account the scattering anisotropy in the multi-group approximation. ANISN solves any order of approximation of the scattering phase function with Legendre polynomials $\left(\mathrm{P}_{\mathrm{N}}\right)$ and using the boundary conditions in the form of albedo, that specify for each energy group of neutrons returning to the system at the boundary [13].

Spectrum of neutrons in the program ANISN calculated for the 22-group splitting of the energy interval. A gamma spectrum was 18-group splitting. For comparison of the protective properties of materials are all design options normalized to one and the same reactor power. The distribution of fluxes of neutrons and $\gamma$-rays, as well as the distribution of dose from neutrons and $\gamma$-rays in materials protection were considered in plane geometry.

Concentrations of elements used in the calculations were determined on the basis of elemental and chemical composition of materials (Tables 1-3). The compositions and volumetric mass of the investigated materials are presented in Table 4.

The elemental composition of the material CTH

Table 1

\begin{tabular}{|c|c|c|c|c|c|c|c|c|c|}
\hline \multicolumn{10}{|c|}{ Element, wt.\% } \\
\hline $\mathrm{Ti}$ & $\mathrm{H}$ & $\mathrm{Fe}$ & $\mathrm{Si}$ & $\mathrm{Al}$ & $\mathrm{C}$ & $\mathrm{O}$ & $\mathrm{N}$ & $\mathrm{Cl}$ & $\mathrm{F}$ \\
\hline 95.0 & 3.44 & 0.2 & 0.1 & 1.0 & 0.07 & 0.15 & 0.04 & $8 \cdot 10^{-4}$ & $3 \cdot 10^{-4}$ \\
\hline
\end{tabular}

Table 2

Elemental composition of THF material

\begin{tabular}{|c|c|c|c|c|c|c|c|}
\hline \multicolumn{7}{|c|}{ Element, wt.\% } \\
\hline $\mathrm{Ti}$ & $\mathrm{H}$ & $\mathrm{Al}$ & $\mathrm{C}$ & $\mathrm{Fe}$ & $\mathrm{Si}$ & $\mathrm{O}$ & $\mathrm{N}$ \\
\hline 95.63 & 3.50 & 0.40 & 0.05 & 0.20 & 0.08 & 0.10 & 0.04 \\
\hline
\end{tabular}

Table 3

Chemical composition of PC, wt.\%

\begin{tabular}{|c|c|c|c|c|c|}
\hline $\mathrm{CaO}$ & $\mathrm{SiO}_{2}$ & $\mathrm{Al}_{2} \mathrm{O}_{3}$ & $\mathrm{Fe}_{2} \mathrm{O}_{3}$ & $\mathrm{MgO}$ & $\mathrm{SO}_{3}$ \\
\hline 65.8 & 20.8 & 4.9 & 3.5 & 2.9 & 2.1 \\
\hline
\end{tabular}

Table 4

Compositions of protection materials

\begin{tabular}{|c|c|c|c|}
\hline No. & $\begin{array}{c}\text { Material, } \\
\text { Composition* }\end{array}$ & $\begin{array}{c}\text { Bulk } \\
\text { weight, } \\
\mathrm{kg} / \mathrm{m}^{3}\end{array}$ & $\begin{array}{c}\text { Nuclear } \\
\text { concentration } \\
\text { of hydrogen, } \\
\times 10^{24} 1 / \mathrm{cm}^{3}\end{array}$ \\
\hline 1 & CTH & 3800 & 0.0747 \\
\hline 2 & $\begin{array}{l}\text { CTH in the masonry, } \\
\text { taking into account } \\
\text { block gaps }\end{array}$ & 3400 & 0.0646 \\
\hline 3 & THF & 2526 & 0.0542 \\
\hline 4 & $\begin{array}{l}\text { CTHF (80.6 wt.\% } \\
\text { DHT, PC, } \\
\text { W/C }=0.8)\end{array}$ & 2790 & 0.0482 \\
\hline 5 & $\begin{array}{l}\text { CTHF (75.8 wt. } \% \\
\text { DHT, PC, } \\
\text { W/C }=0.3)\end{array}$ & 2970 & 0.0476 \\
\hline 6 & $\begin{array}{l}\text { CTHF (90.4 wt.\% } \\
\text { DHT, PC, } \\
\text { W/C = 0.9) }\end{array}$ & 3127 & 0.0568 \\
\hline 7 & $\begin{array}{l}\text { CTHF (85.5 wt. } \% \\
\text { DHT, PC, } \\
\text { W/C }=0.27) \\
\end{array}$ & 3262 & 0.0558 \\
\hline 8 & $\begin{array}{l}\text { CTHF with boron } \\
(84.5 \text { wt. } \% \text { DHT, } \\
\text { PC, BA, } \\
\text { W/C }=0.27) * *\end{array}$ & 3262 & 0.0552 \\
\hline 9 & $\begin{array}{l}\text { Serpentinite concrete } \\
\text { (serpentinite - } \\
80.4 \%, \mathrm{PC}-17.2 \%, \\
\mathrm{~W} / \mathrm{C}=0.75 \text { ) }\end{array}$ & 2100 & 0.0163 \\
\hline
\end{tabular}

*Water-cement ratio (W/C) of the prepared mixture;

**boron-containing additive (BA) $5 \mathrm{wt} \%$.

In variant calculations, compositions consisting of a reactor core, reactor structural elements, a reflector, and a layer of the protective material under study $1 \mathrm{~m}$ thick (which corresponds to the thickness of the hydrogencontaining layer in real protection) were considered. Moreover, in the calculations it was assumed that the protective material is located immediately after the steel reactor vessel with a thickness of $125 \mathrm{~mm}$, which allows gamma rays to leak from the core, the reactor structures, and the reactor vessel.

\section{RESULTS AND ITS DISCUSSION}

The results of calculating the functionals are presented in Figs. 1-4, which shows the nature of the distribution of the flux density of fast and thermal neutrons, as well as the dose rate of neutron and gamma radiation over the thickness of the protection materials.

As follows from the figures, in a first approximation, neutron attenuation can be described by a simple expression (1):

$$
\Phi(d)=\Phi_{0} \cdot e^{-d / \lambda}
$$


where $\Phi_{0}-$ neutron flux density without protection; $\Phi(d)$ - neutron flux density behind a layer of protection thick $d, \mathrm{~cm} ; \lambda$ - neutron relaxation length, $\mathrm{cm}$.

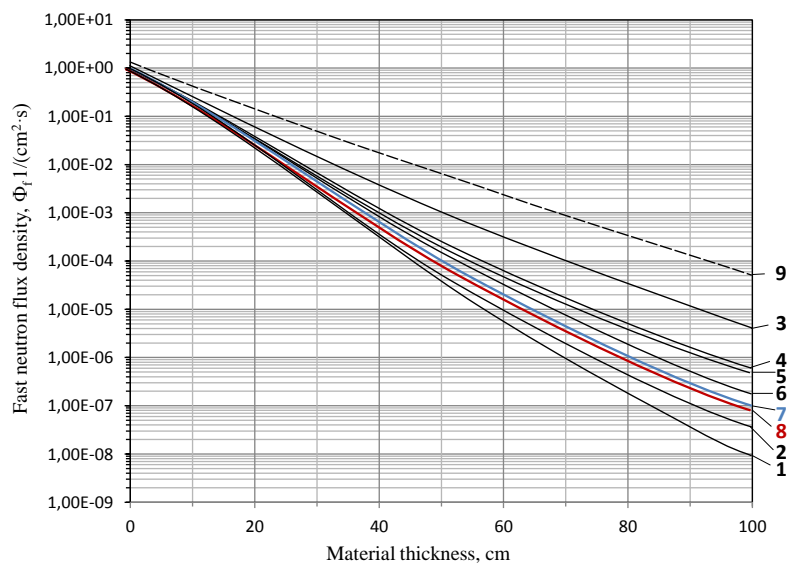

Fig. 1. Distribution of fast neutron flux density $\left(\Phi_{f}\right)$ in materials No. $1-9$

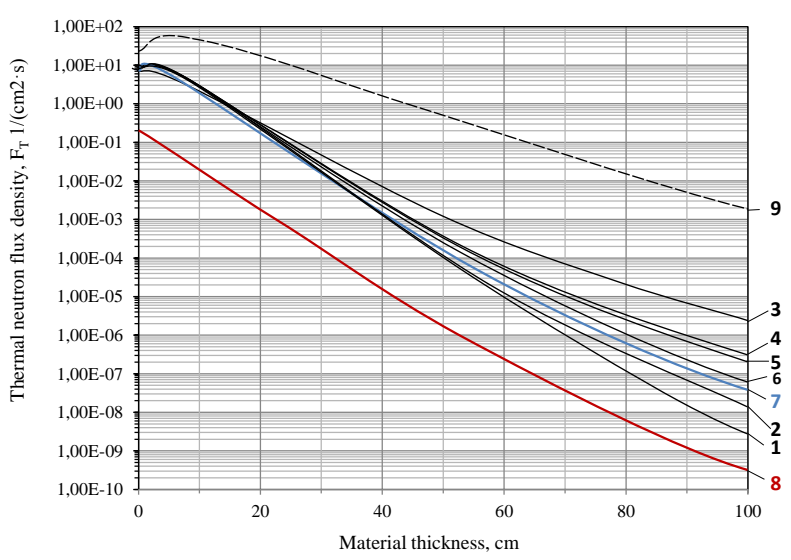

Fig. 2. Distribution of the flux density of thermal neutrons $\left(\Phi_{t}\right)$ in materials No. 1-9

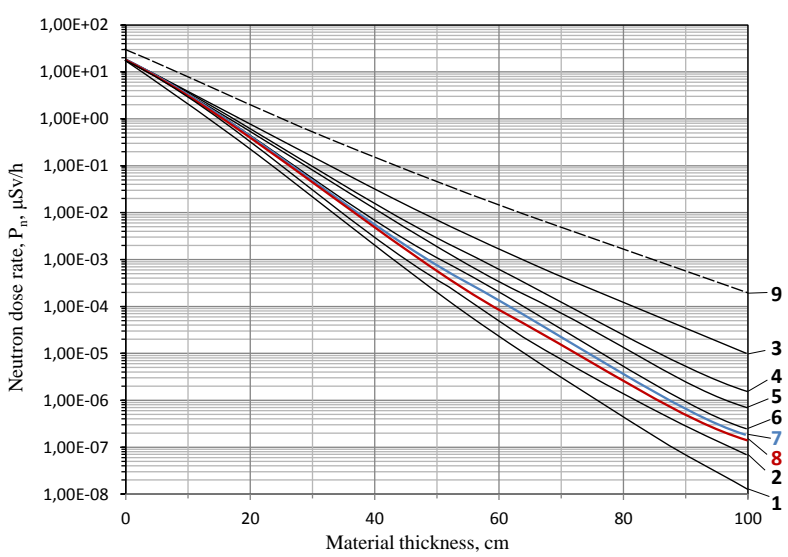

Fig. 3. Distribution of neutron dose rate $\left(P_{n}\right)$ in materials No. 1-9

The calculations showed that the spatial-energy distribution of neutron radiation in the material is formed by fast neutrons. The nature of the distribution of the dose rate of gamma radiation $\left(\mathrm{P}_{\mathrm{r}}\right)$ over the thickness of the protection and its value behind the protection determines the radiation flowing onto the front wall and the capture gamma radiation generated in the initial layer of the material, a few centimeters thick (and for the materials under consideration, in our calculation composition reactor protection, the first component is less than the second). In this case, with an increase in the layer thickness, an equilibrium spectrum is established for fast and thermal neutrons. Therefore, when comparing the protective properties of materials in this case, the value of the fast neutron flux density can be considered as the main criterion. The same pattern is followed by a weakening of the dose rate of a neutron study.

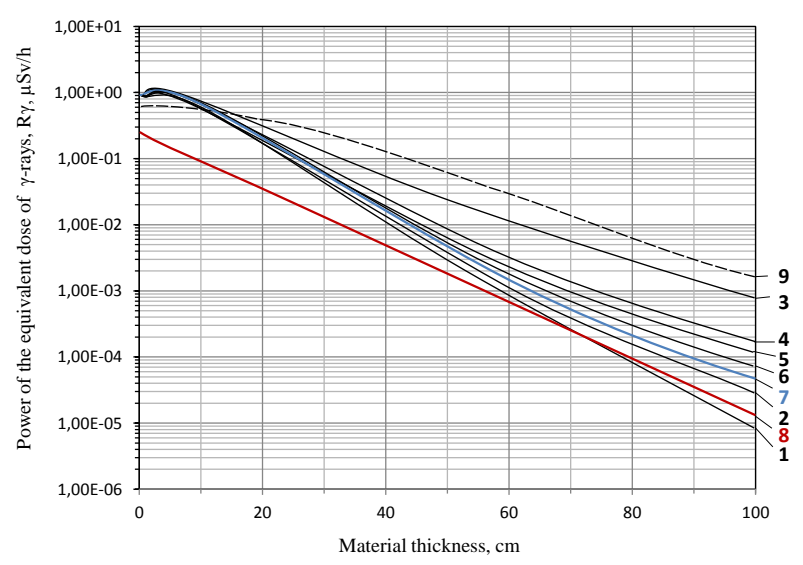

Fig. 4. The distribution of the equivalent dose rate of gamma-rays $\left(P_{\gamma}\right)$ in materials No. 1-9

The introduction of boron atoms into the composition (composite No. 8), which has a high absorption cross section of slow neutrons (thermal and epithermal), significantly reduces the thermal neutron flux density and capture gamma radiation. Moreover, it has almost no effect on the fast neutron flux density $\left(\Phi_{\mathrm{f}}\right)$ and neutron dose rate $\left(\mathrm{P}_{\mathrm{n}}\right)$. A similar material without boron is material No. 7. Compared to material No. 7, behind material No. 8, the value $\Phi_{\mathrm{t}}$ at a thickness of $1 \mathrm{~m}$ decreases 95 times, and the value of $\mathrm{P}_{\gamma}$ decreases 3.7 times.

Table 5

The relaxation length of fast neutrons $\left(\lambda_{\mathrm{f} . \mathrm{n}}, \mathrm{cm}\right)$ on the thickness of the protective layer $(\mathrm{h}, \mathrm{cm})$ of materials

\begin{tabular}{|c|c|c|c|}
\hline \multirow{2}{*}{$\begin{array}{c}\text { No. } \\
\text { material }\end{array}$} & \multicolumn{3}{|c|}{$\lambda_{\text {f.n. }}(\mathrm{h}), \mathrm{cm}$} \\
\cline { 2 - 4 } & $0 \ldots 30$ & $30 \ldots 60$ & $60 \ldots 100$ \\
\hline 1 & 4.3 & 5.4 & 6.3 \\
\hline 2 & 4.8 & 6.0 & 6.9 \\
\hline 3 & 6.8 & 7.9 & 9.3 \\
\hline 4 & 5.9 & 6.9 & 7.9 \\
\hline 5 & 5.8 & 6.7 & 7.6 \\
\hline 6 & 5.2 & 6.3 & 7.3 \\
\hline 7 & 5.1 & 6.1 & 7.0 \\
\hline 8 & 5.2 & 6.2 & 7.1 \\
\hline 9 & 9.3 & 9.7 & 10.1 \\
\hline
\end{tabular}

The relaxation lengths of the fast neutron flux density and the dose rate of gamma radiation in the materials under study, obtained on the basis of the calculation data for the attenuation of the functionals of neutron and gamma radiation, are presented in Tables 5 and 6.

The relaxation length $\lambda$ at the layer thickness $d=d_{1}-$ $d_{2}$ was determined from the relationship (2) and 3):

$\lambda=\left(d_{1}-d_{2}\right) / \ln \left(\Phi\left(d_{1}\right) / \Phi\left(d_{2}\right)\right)$,

$\lambda=\left(d_{1}-d_{2}\right) / \ln \left(\mathrm{P}\left(d_{1}\right) / \mathrm{P}\left(d_{2}\right)\right)$, 
where $\Phi\left(d_{1}\right), \Phi\left(d_{2}\right)$ and $\mathrm{P}\left(d_{l}\right), \mathrm{P}\left(d_{2}\right)$ - accordingly, the neutron flux density and the dose rate of gamma rays on the thickness of the protection layer $d_{1}$ and $d_{2}$.

Table 6

The relaxation length of the dose rate of gamma rays $\left(\lambda_{\mathrm{t}} \mathrm{cm}\right)$ on the thickness of the protection layer $(\mathrm{h}, \mathrm{cm})$ of materials

\begin{tabular}{|c|c|c|c|}
\hline \multirow{2}{*}{$\begin{array}{c}\text { No. } \\
\text { material }\end{array}$} & \multicolumn{3}{|c|}{$\lambda_{\mathrm{\Gamma}}(\mathrm{h}), \mathrm{cm}$} \\
\cline { 2 - 4 } & $0 \ldots 30$ & $30 \ldots 60$ & $60 \ldots 100$ \\
\hline 1 & 8.3 & 8.8 & 9.3 \\
\hline 2 & 9.1 & 9.7 & 10.3 \\
\hline 3 & 12.3 & 13.6 & 14.9 \\
\hline 4 & 10.4 & 11.4 & 12.4 \\
\hline 5 & 9.9 & 10.8 & 11.7 \\
\hline 6 & 9.6 & 10.4 & 11.1 \\
\hline 7 & 9.2 & 9.9 & 10.5 \\
\hline 8 & 10.1 & 10.1 & 10.5 \\
\hline 9 & 13.6 & 14.7 & 15.7 \\
\hline
\end{tabular}

In the physical sense, the relaxation length $\lambda$ indicates the thickness of the layer of material, where the density of neutron flux is attenuated in $e$ times $(e=2.718)$.

Analysis of the obtained data (see Tables 5 and 6) shows that with the increase of the thickness calculated layer of the investigated material, the value of the relaxation length of rapid neutrons $\lambda_{\text {f.n. }}$ gradually increases, tending to a constant value.

This is due to tightening of neutron spectrum on the thickness, which in turn is connected with the energy dependence of the scattering of fast neutrons on hydrogen atoms of materials. The attenuation of the neutron dose rate by protection from materials based on THF actually corresponds to the attenuation of the fast neutron flux density.

The increase of hydrogen content in the material leads to a decrease in the value $\lambda_{\text {f.n. }}$ (see Table 5), and this dependence decreases with increase in the thickness of the material. This may be due to the energy loss of neutrons to the thickness of the protection and reduction of the processes of elastic scattering on hydrogen. This trend is most pronounced in the composite of No. 7, where the values of the relaxation length of rapid neutrons with a layer thickness of $60 \ldots 100 \mathrm{~cm}$ is comparable to $\lambda_{\text {f.n. }}$ for material No. 2 on the basis of the $\mathrm{CTH}$ in the masonry.

In the composites the presence of hydrogen due to the content of the hydride phase. The presence of hydrogen due to its content in the associated water of the cement stone has a much smaller impact on the protective properties of materials. In this regard, compositions with a reduced content of bound water, which is removed after heat treatment, its protective properties are not inferior to the materials of the same density with PC in which part of the bound water remains.

Since the protection materials under consideration have weaker protective properties with respect to gamma radiation than with thermal neutrons $\left(\lambda_{\gamma}>\lambda_{t}\right)$, the primary gamma radiation that arises before the protection and capture gamma radiation generated in the initial layers of protection will be weaken less than the profit of new gamma rays generated by the capture of thermal neutrons. In this regard, with increasing thickness of the protection $\lambda_{\gamma}$ increases (see Table 6). However, due to the considerable attenuation of thermal neutrons arising secondary gamma radiation is not a significant contributor to the total dose rate of gamma rays for protection. This explanation is particularly well illustrated by the example material No. 8 with boron with the highest value of attenuation of thermal neutrons, where the value $\lambda_{\gamma}$ throughout the thickness of the protection is practically the same. Thus, the dose of gamma rays in a material is mainly determined by the capture gamma quanta arising in the initial layer of protection and the formation capture gamma rays across the thickness of protection are irrelevant. As a result, the relaxation length of the dose rate of gamma radiation in these materials is almost independent of the content of hydrogen.

Calculations show high efficiency of the described materials. The length of the relaxation of $\Phi_{\mathrm{f}}$ materials based on THF is an average of $5.1 ; 6.1$, and 7.0 (material No. 7) for thicknesses of 0 to 30; 30 to 60 and $60 \ldots 100 \mathrm{~cm}$, respectively. The formula of attenuation material No. 7 on the layer thickness $1 \mathrm{~m}$ to more than $\sim 3$ orders of magnitude greater than is widely used in protecting nuclear facilities serpentinite concrete. For products of the SCC in the masonry with the actual density $3.4 \mathrm{~g} / \mathrm{cm}^{3}$, the corresponding values of the lengths of the relaxation of $\Phi_{\mathrm{f}}$ is $4.8 ; 6.0$, and $6.9 \mathrm{~cm}$.

The introduction of boron atoms into the composite slightly increases the value of $\lambda_{\gamma}$ (materials No. 8 and 7) at a thickness of $30 \ldots 60 \mathrm{~cm}$ due to the tightening of the neutron spectra in the thermal and previous thermal regions. At the same time, the absolute value of the flux density of thermal neutrons is reduced. The resulting total effect is a substantial reduction of dose rate of gamma radiation.

Data analysis of Tables 4-6 shows that increasing the density of the material decreases the length of the relaxation, as for neutron and gamma radiation. For gamma radiation this process is more pronounced and amounts to $26 \%$ in the thickness of the layer $30 \ldots 60 \mathrm{~cm}$ and $28 \%$ and a thickness of $60 \ldots 100 \mathrm{~cm}$, i.e. almost independent of the layer thickness.

Calculations show that increasing the density of protection to $3.2 \ldots 3.3 \mathrm{~g} / \mathrm{cm}^{3}$ allows reducing the length of neutron relaxation to $6.0 \ldots 7.0 \mathrm{~cm}$, which is $2.2 \ldots 2.4$ times less than in serpentinite concrete. This means that with the same neutron attenuation factor, the thickness of protective composites based on titanium hydride and PC will be $\sim 2$ times less than serpentinite concrete.

Thus, on the basis of the multi-group modeling, the high efficiency of materials based on titanium hydride is shown when used in the protection of transport NPP instead of serpentinite concrete. Composite materials based on fractions of titanium hydride and a PC binder, which have a monolithic protective structure in comparison with materials based on $\mathrm{CTH}$, are most effective. In this case, the introduction of boron atoms into the material of protection leads to a decrease in the flux density of thermal neutrons and the level of dose rate of capture gamma radiation 


\section{CONCLUSION}

Multi-group modeling of the processes of interaction between the radiation of the active zone of a nuclear power reactor and materials based on titanium hydride has shown that gamma radiation behind the protection is formed by capture radiation flowing from the steel reactor shell. Secondary gamma radiation generated by the passage of a neutron flux through the thickness of the composite does not significantly affect the value of the gamma ray functional for protection.

The calculations showed the high efficiency of materials based on THF. According to the efficiency of attenuation of neutron and gamma radiation, materials based on fractions of titanium hydride and cement binder (CTHF) are not much inferior to the CTH material in the masonry, and they are an order of magnitude higher than the protective properties of the fraction without a binder (THF) due to the absence of neutron slip and denser particle packing. In comparison with serpentinite concrete, the dose rate of neutrons and gamma rays in CTHF is much less. The introduction of boron atoms into the protective composition reduces the level of capture gamma radiation, but does not affect the attenuation of fast neutrons. The use of fractions of titanium hydride without a binder is unreasonable because of the possible formation of voids in the protection and slip of neutrons.

\section{ACKNOWLEDGEMENTS}

The reported study was funded by RFBR, project number 19-38-90024.

\section{REFERENCES}

1. V.V. Perevezencev. Fundamentals of engineering methods for calculating the protection against ionizing radiation of nuclear power plants. M.: "Publishing house of MSTU", 1994, 68 p.

2. John C. Lee, Norman J. McCormick. Risk and Safety Analysis of Nuclear Systems // John Wiley \& Sons, Inc. 2011, p. 504.

3. N. Itoigawa, B. Wilpert, B. Fahlbruch. Emerging Demands for the Safety of Nuclear Power Operations:
Challenge and Response. CRC Press, Boca Raton, FL. 2005, p. 153.

4. G. Antaki, R. Gilada. Nuclear Power Plant Safety and Mechanical Integrity: Design and Operability of Mechanical Systems, Equipment and Supporting Structures. Butterworth-Heinemann, Kidlington, Oxford, 2015, p. 337.

5. V.M. Chernov. Structural materials for fusion power reactors - the RF R\&D activities // Nuclear Fusion. 2007, v. 47, N 8, p. 839-848.

6. H. Yoshikawa, Zh. Zhang. Progress of Nuclear Safety for Symbiosis and Sustainability: Advanced Digital Instrumentation, Control and Information Systems for Nuclear Power Plants. Springer, Tokyo, 2014, p. 322.

7. K.E. Sickafus et al. Radiation-induced amorphization resistance and radiation tolerance in structurally related oxides // Nature materials. 2007, N 6(3), p. 217-223.

8. F. Sanchez, K. Sobolev. Nanotechnology in concrete - A review // Construction and Building Materials. 2010, v. 24, p. 2060-2071.

9. R.N. Yastrebinsky. Distribution neutron and gamma of radiation in the protective composite with various content of atoms of boron // Problems of Atomic Science and Technology. 2016, N 5(105), p. 66-72.

10. R.N. Yastrebinsky. Decrease gripping gammaradiation scale composite neutron and protective material on the basis of the modified hydride of the titan with various content of atoms of bor // Problems of Atomic Science and Technology. 2017, N 4(110), p. 103-106.

11. A.N. Golubkov et al. Manufacturing technology development for hydrogenated titanium pellets // Proceedings of the RFNC-VNIIEF. 2017, N 2, p. 158163.

12. W.W. Jr. Engle. A User's Manual for ANISN. A One-Dimensional Discrete Ordinates Transport Code with Anisotropic Scattering, K-1693. Union Carbide Corporation: Radiation Shielding Information Center (RSIC), CCC-254, 2007.

13. B. Carlson, C. Latrop. Transfer theory. Discrete ordinate method. M.: "Atomizdat", 1972, 458 p.

\section{МНОГОГРУППОВОЕ МОДЕЛИРОВАНИЕ ЗАЩИТЫ ОТ НЕЙТРОННОГО И ГАММА-ИЗЛУЧЕНИЯ МАТЕРИАЛАМИ НА ОСНОВЕ ГИДРИДА ТИТАНА}

\section{Роман Н. Ястребинский, Александр А. Карнаухов}

Дана сравнительная расчетная оценка радиационно-защитной эффективности различных композиционных материалов на основе гидрида титана с использованием методов многогруппового моделирования по программе ANISN. Расчеты показали высокую эффективность композитов на основе гидрида титана по отношению к нейтронному и гамма-излучению. Длина релаксации плотности потока быстрых нейтронов в материалах на основе гидрида титана составляет 5,1..7,0 см. Пространственноэнергетическое распределение нейтронного излучения в материалах формируется быстрыми нейтронами. Мощность дозы гамма-квантов за материалом определяется в основном захватными гамма-квантами, возникающими в начальном слое защиты. Введение в состав защиты атомов бора снижает уровень захватного гамма-излучения, но не влияет на ослабление быстрых нейтронов. 


\title{
БАГАТОГРУПОВЕ МОДЕЛЮВАННЯ ЗАХИСТУ ВІД НЕЙТРОННОГО І ГАММА- ВИПРОМІНЮВАННЯ МАТЕРІАЛАМИ НА ОСНОВІ ГІДРИДУ ТИТАНУ
}

\author{
Роман Н. Ястребинський, Олександр А. Карнаухов
}

Дано порівняльна розрахункова оцінка радіаційно-захисної ефективності різних композиційних матеріалів на основі гідриду титану з використанням методів багатогрупового моделювання за програмою ANISN. Розрахунки показали високу ефективність композитів на основі гідриду титану по відношенню до нейтронного і гамма-випромінювання. Довжина релаксації щільності потоку швидких нейтронів у матеріалах на основі гідриду титану становить $5,1 \ldots 7,0$ см. Просторово-енергетичний розподіл нейтронного випромінювання в матеріалах формується швидкими нейтронами. Потужність дози гамма-квантів за матеріалом визначається в основному захватними гамма-квантами, що виникають у початковому шарі захисту. Введення до складу захисту атомів бору знижує рівень захватного гамма-випромінювання, але не впливає на ослаблення швидких нейтронів. 